\title{
STUDY OF TOURISM POTENTIAL OF “TEBING KOJA", CIKUYA VILLAGE, SOLEAR DISTRICT, TANGERANG CITY, BANTEN PROVINCE
}

\author{
Hendry HARTONO*, Haryadi SARJONO, Hardijanto SAROSO, and Sasmoko SASMOKO \\ Management Department, Binus Business School Undergraduate Program, Bina Nusantara University, Indonesia \\ *hhartono@binus.edu
}

\begin{abstract}
This paper wants to reveal how the verification process of tourist villages by using a set of instruments elements of tourist villages based on the study of existing legislation and literature. By using the instrument elements of tourism villages, researchers use qualitative methods by conducting holistic, and participatory approaches. The instrument is divided into eleven elements of tourism village and has been through verification and validation of instruments through expert judgment. The research was conducted for 3 months, namely from March 2021 to May 2021. The results revealed that tourist destinations fall into the category of "Simply Qualify" which has the potential and needs the right strategy to be able to develop existing potentials so that it becomes even better. Thus, the results of the research Grants Excellence Study Program has been through the process of downstream research results by the mandate of the Directorate General of Strengthening Research and Development Results, Ministry of Education and Culture of the Republic of Indonesia.
\end{abstract}

Keywords: Tebing Koja, Community Welfare, Tourism, Strategic Development

\section{BACKGROUND}

Community welfare becomes an important issue from year to year, and the village is the smallest territorial unit in a country, especially the Republic of Indonesia, where according to the Village Law (UU No. 6 of 2014) where the Village is a legal community unit that has territorial boundaries, which is authorized to regulate and manage governmentaffairs, the interests of thelocal communitybased on community initiatives, origin rights, and or traditional rights that are recognized and respected in the system of government of Indonesia. The welfare of rural communities is often considered slow compared to improving the welfare of people in urban areas. As reported by the Ministry of Villages, Development of Disadvantaged Regions and Transmigration (Kemendes PDTT) noted, 294 out of 1,238 villages in Banten Province are still underdeveloped and 16 other villages are very underdeveloped, spread across Lebak Regency, Pandeglang Regency, and Serang Regency. The status of villages in Banten Province that is underdeveloped and very underdeveloped is known based on the Decree of the Director-General of Village Community Development and Empowerment Number 303 of 2020. One of the efforts that can be done is to encourage village economic movement through village entrepreneurship, where village entrepreneurship is a strategy in development and growth. well-being (Roundy, 2019).

At the beginning of the observations made and based on questions and answers with Mrs. Jalis (local community leader) and Mr. Uus (one of the owners of the Koja Cliff tourist land). The first initiation is to study potential tourism destinations in this village. From the results of the initial interviews, it can be concluded that this tourist destination still needs to be prepared and improved. Mrs. Jalis and Mr. Uus himself admit that this destination still needs the help of other parties to be able to help identify what are the shortcomings and what needs to be improved, the important thing is that this tourist destination can make a positive contribution to the community. They both identified that the number of tourists who come varies, and the number of tourists is very dependent on the moment of year-end holidays and Eid Mubarak, so it is felt that it is not too significant to help the community because the impact has not been felt evenly if seen from the efforts made by the community to build this area especially very much. The impact was felt when the Covid-19 pandemic spread even though this area had implemented the health protocol quite well.

The problem-solving strategy can use a developing village approach which includes: (1) Rural development is adjusted to the national development strategy and regional development; (2) Rational and optimal utilization of village potential without disturbing the balance and preservation of nature; (3) Development of a strong foundation for rural communities to grow and develop on their abilities; (4) Utilization of science and technology; and (5) Encouraging village communities to play an active role in development activities (Andoko, 2019).

Before going to the problem solving, this paper tries to verify and identify tourist villages using a set of tourist village criteria instruments, where the results of this verification can identify village conditions and village needs so that by verifying with a set of tourist village criteria instruments can provide a better picture. which will later be able to provide a comprehensive, systematic picture of the situation and needs of the village, which will later be able to provide input on priority village development program strategies that are more precise, directed and have a significant impact The orientation of developing a tourist village should be to improve the welfare of the village community. This effort requires patience in conducting assessments, planning, development, and use fairly and equitably, both for nature and humans. Not only do humans have rights, but the natural environment also has rights that must and must be fulfilled by humans who use them. Optimization of carrying capacity requires a good understanding of the character, dynamics, and trends that develop (Faizal Rachman \& Suprina, 2019; Nayati Utami \& Ruhana, 2019). 
According to Law no. 19 of 2009, Tourism is defined as a travel activity carried out by a person or group of people by visiting certain places for recreational purposes, personal development, or studying the uniqueness of tourist attractions visited in a temporary period. Tourism Destinations or tourist destinations are geographical areas located in one or more administrative areas in which there are tourist attractions, public facilities, tourism facilities, accessibility, and communities that are interrelated and complement the realization of tourism. The tourist attraction is everything that has uniqueness, beauty, and value in the form of the diversity of natural wealth, culture, man-made products that are the target or destination of tourists.

Based on Law no. 6 of 2014, Villages (including traditional villages) are legal community units that have territorial boundaries that are authorized to regulate and manage government affairs, the interests of local communities based on community initiatives, origin rights, and/or traditional rights that are recognized and respected in the government system. The Unitary State of the Republic of Indonesia. Rural areas are areas that have main agricultural activities, including the management of natural resources with the composition of the function of the area as a place for rural settlements, government services, social services, and economic activities. Rural Tourism is a type of tourism product that is located in a village or in several villages that form a unitary rural area, developed without having to turn rural areas into urban areas.

The development of rural tourism destinations must follow the following norms:

1. Upholding religious norms and cultural values as a manifestation of the concept of life in the balance of the relationship between man and God Almighty, the relationship between man and fellow human beings, and the relationship between man and the environment.

2. Uphold human rights, cultural diversity, and local wisdom.

3. Benefiting the welfare of the people, empowering local communities, justice, equality, and proportionality.

4. Maintaining the sustainability of nature and the environment.

5. Empowering local communities.

6. Ensuring cohesion between sectors, between regions, between the center and the region which is a systemic unity within the framework of regional autonomy, as well as cohesion between stakeholders.

7. Comply with the world's tourism code of conduct and international agreements in the field of tourism.

8. Strengthening the integrity of the Unitary State of the Republic of Indonesia.

The development of rural tourism destinations should refer to various applicable laws and regulations but not limited to:

1. Law No. 10 of 2009 on Tourism

2. Government Regulation Number 50 of 2011 concerning
The Master Plan of National Tourism Development 2010-2025

3. Presidential Regulation No. 63 of 2014 on Supervision and Control of Tourism Implementation

4. Presidential Regulation No. 64 of 2014 on Strategic Coordination across Sectors Tourism Management

5. Presidential Regulation No. 19 the Year 2015 On The Ministry of Tourism

6. Regulation of the Minister of Culture and Tourism Number PM86. HK.501/MKP/2010 On Procedures for Accommodation Business Registration

7. Regulation of the Minister of Tourism No. 9 of 2014 concerning Pondok Wisata Business

8. Regulation of the Minister of Home Affairs No. 33 of 2009 concerning Guidelines for Ecotourism Development in the Region

Tourism in the village or rural tourism is one of the alternative forms of tourism today for tourists. Alternative tourism is a more nature-oriented tourism concept and local people cannot get the ethics of visiting tourist destinations in general. This rural tourism which is part of the sustainable tourism development and has become one of the programs of the Government of the Republic of Indonesia that is expected to trigger economic growth based on community empowerment. Being a tourist village is not easy and not every village can be used as a tourist village because at least 3 components are needed to build it. First, by looking at the potential of tourism available. Here the local government must have a clear database of land, location, area, and how the ecosystem can help the development of tourist destinations later. Second, by looking at the interest and readiness of the community towards the development of local tourist destinations. The tourism village will be very developed if managed by the village itself, the need for organizations that specialize in managing the tourist village is needed to be sustainable and involve parties that determine the direction of the tourist village. Third, is the concept of a tourist village that must be unique. With different concepts or ideas of tourists, villages will be a prominent selling point among tourist destinations in other areas.

The formation of this tourism village concept can be sharper if combined with the mapping of the area done in the beginning. If mapped, then there are 4 levels of tourist villages as below:

1. Pioneer. It is still potential and there is no tourist visit. In addition, the facilities and infrastructure are still very limited, with the level of public awareness has not grown.

2. Developing. Although it is still a potential, it has begun to be looked at to be developed further.

3. Developed. The community is already aware of tourism with indicators that can already manage tourism business, including using village funds to develop tourism potential. The area has also been visited by many tourists, including from abroad. 
4. Self-sufficient. There has been tourism innovation from the community, the tourist destination has also been recognized by the world with standardized facilities and infrastructure. In addition, the management is collaborative Penta-helix.

Referring to the Regulation of the Minister of Tourism of the Republic of Indonesia Number 29 of 2015, the development of rural-based tourism (tourist villages) will drive tourism economic activity in the countryside that will prevent the urbanization of rural communities to the city. The development of rural tourism will encourage the preservation of nature (landscapes, rice fields, rivers, lakes) which in turn will have an impact on reducing global warming. Tourism village program continues to grow as alternative tourism is expected to make a positive contribution to community development(Budhi Pamungkas Gautama, Yuliawati, Nurhayati, Fitriyani, \& Pratiwi, 2020; Hidayati \& Nugrahani, 2021; Subarkah, 2018).

\section{METHOD}

This study uses a qualitative approach through primary and secondary data. Search begins by collecting legal products, and past research related to research topics. Semi-structured interviews were conducted to find out the condition of the village with 6 people, namely local government, and local community leaders. Based on the results of the initial interview, researchers finally decided to take several approaches in this study, among others: The holistic Approach. This approach is felt to be able to integrate the criteria elements that form the basis of research built by researchers so that the formulation of problems and their solutions can be done collectively and participatory. This is intended to open understanding and align the context of the problem so that formulating policies and development can be appropriate. The second approach is Participatory Learning. It is also intended in the development of villages that need to be done participatory where together digging the needs and formulate together what is the priority and how to solve it. Returning to the problems faced by the village, the problem faced by the village that knows best is the villagers themselves.

The research was conducted within 3 months, namely March 2021 to May 2021 in the condition of the Covid-19 pandemic so that the interview procedure is conducted face-to-face, and the rest is done with an online approach face-to-face with the phone call option, WhatsApp in accordance with a convenient schedule for the resource person. The criteria instruments are based on literature studies and guidebooks of tourist villages and weighting assessments through an intensive discussion process with several experts and practitioners of tourism, especially tourist villages. The research continued with the measurement instrument collectively structured with a holistic and participatory learning approach to previous sources. Ultimately, the instrument context analysis procedure is used to provide appropriate information.

\section{RESULTS AND DISCUSSIONS}

As an instrument for verification of factual assessment by involving 6 resource persons, namely local government and community leaders against tourist destinations Tebing Koja, researchers compiled 11 criteria of destination elements, among others; Identity; Regional; Tourist Attraction; Activities; Accessibility and Ease of Traveler Mobility; Amenities; Community Empowerment; Investment; Tourism Business; Institutional; marketing. The process of realizing the criteria of tourist destination elements based on the search of literature and travel manuals, and the weighting of each element as an assessment through an intensive discussion process with several experts and practitioners of tourism, especially tourist villages.

Table 1. Elements of Tourism Village

\begin{tabular}{|c|c|c|c|}
\hline No. & $\begin{array}{l}\text { DESTINATION } \\
\text { ELEMENTS }\end{array}$ & DESCRIPTION & WEIGHT \\
\hline 1 & IDENTITY & $\begin{array}{l}\text { Villages and rural areas as a tourism destination must have a rural identity in } \\
\text { Indonesia. The identity of a place can be felt by human senses-visionors, } \\
\text { listeners, kissers, tasters, and tasters. Therefore, it needs to be realized through } \\
\text { various aspects of tourism product components in villages and/or rural areas. } \\
\text { Tourism development in rural areas needs to maintain a rural atmosphere that }\end{array}$ & $10 \%$ \\
\hline 2 & REGIONAL & $\begin{array}{l}\text { Product development in rural areas must be harmonious/in harmony with } 1 . \\
\text { Development plans by the central government in the region; } \\
\text { 2. Provincial government development plan; } \\
\text { 3. Development plan of the district/city government where the village/village is } \\
\text { located; and } \\
\text { 4. Village/village development plan related to }\end{array}$ & $10 \%$ \\
\hline \multirow[b]{3}{*}{3} & \multirow[b]{3}{*}{$\begin{array}{c}\text { TOURIST } \\
\text { ATTRACTION }\end{array}$} & 1. There is a tourist attraction. & $1 \%$ \\
\hline & & $\begin{array}{l}\text { 2. Every important and potential tourist attraction is known / explored its } \\
\text { meaning, its story, its role. Get to know the relationship of resources or tourist } \\
\text { attractions with the local community. }\end{array}$ & $1 \%$ \\
\hline & & $\begin{array}{l}\text { 3. The status of ownership of tourist attractions in rural areas can be Within the } \\
\text { authority of the government of a village or traditional village as happened in the } \\
\text { villages }\end{array}$ & $1 \%$ \\
\hline
\end{tabular}




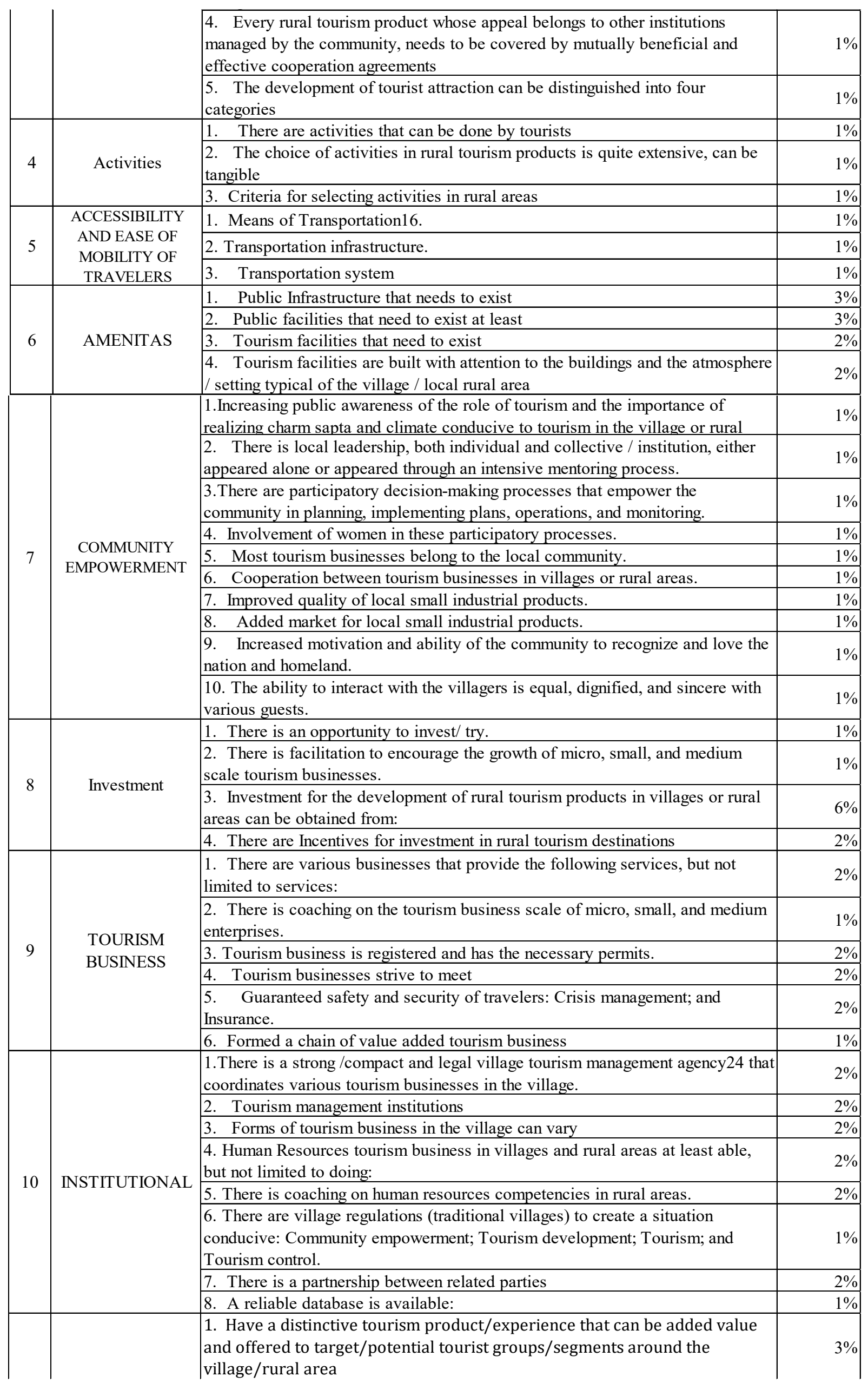




\begin{tabular}{|c|c|c|c|}
\hline \multirow{5}{*}{11} & \multirow{5}{*}{ MARKETING } & 2. Have a reasonable price / worth the experience offered. & $2 \%$ \\
\hline & & 3. Have Website and Print Promotional Materials & $4 \%$ \\
\hline & & 4. Have a network of marketing cooperation horizontal and vertical & $3 \%$ \\
\hline & & 5. Go to various books and/or travel guide sites. & $1 \%$ \\
\hline & & $\begin{array}{l}\text { 6. The presence of tourists in accordance with the planned tourism } \\
\text { products. }\end{array}$ & $2 \%$ \\
\hline & & TOTAL WEIGHT & $100 \%$ \\
\hline
\end{tabular}

Based on the verification instrument of the tourism village above, researchers approached six stakeholder speakers in Cikuya village, namely local government, and Community leaders. The results obtained are as follows:

Table 2. Results of Verification weighting Elements Of Tourist Destinations

\begin{tabular}{|c|l|c|}
\hline No. & \multicolumn{1}{|c|}{ Destination Elements } & $\begin{array}{c}\text { Weighted } \\
\text { Score }\end{array}$ \\
\hline 1 & Identity & 0,1667 \\
\hline 2 & Regional & 0,2000 \\
\hline 3 & Tourist Attraction & 0,0900 \\
\hline 4 & Activities & 0,1067 \\
\hline 5 & Accessibility and Ease of Mobility of Travelers & 0,0800 \\
\hline 6 & Amenitas & 0,1850 \\
\hline 7 & Community Empowerment & 0,1583 \\
\hline 8 & Investment & 0,2417 \\
\hline 9 & Tourism Business & 0,2150 \\
\hline 10 & Institutional & 0,1967 \\
\hline 11 & Marketing & 0,3133 \\
\hline & Total Score & $\mathbf{1 , 9 5 3 3 3}$ \\
\hline
\end{tabular}

The weighting category of verification results is based on the category of Highly Qualified $(>3.25-4.00)$, Qualified $(>2.50-3.25)$, Simply Qualified $(>1.75-2.50)$, Underqualified $(1.00-1.75)$. Based on these categories, the results of verification in this study can be concluded that the tourist village "Tebing Koja" is in the category of "Simply Qualified". By using this instrument will be a reference that will greatly help stakeholders to be able to formulate the next development strategy appropriate. Pay attention to the results obtained and based on further discussions on verification scores to stakeholders where it becomes mutual understanding and learning with stakeholders which can focus more on the elements that become potentials that need to be developed further and which elements need to be the main concern to increase the potential of this tour to be better in the future.

In marketing element which has the highest score, it is understood that quite a lot of reviews on social media about this destination such as YouTube and Facebook, and in general tourists know this destination through social media. Identity unification becomes very important, because there is still a double identity circulating in the community namely "Koja Cliff”, "Godzilla Cage”, and some mention as Kabayan Village Tourism because it is very close to Kabayan Village adjacent to Cikuya Village. There are two accesses to tourist sites and no supporting transportation to get to the location, so tourists who go to the location are dominated by tourists who drive privately compared to those who drive public although it is quite close to the Train Station "Maja".

Problem solving strategies can use a village building approach that includes: (1) Rural development adapted to national development and regional development strategies; (2) Utilization of village potential rationally and optimally without disturbing the balance and sustainability of nature; (3) The development of a strong foundation for the villagers to grow and develop on their own abilities; (4) Utilization of science and technology; and (5) Encourage the villagers to play an active role in development activities(Budhi Pamungkas Gautama et al., 2020)

Based on strategic environmental conditions, several alternative strategies can be identified in relation to answering the results of verification of destination elements "Tebing Koja", as follows: First, related to strengthening the identity and utilization of village potential in a sustainable manner, it is necessary to realize an inherent and directed identity to support a more appropriate marketing strategy. Second, Cikuya village development planning needs to be optimized and contextually translated so that it includes tourism village planning involving village deliberation activities by actively involving all stakeholders from village and subdistrict level to district/province while paying attention to district and provincial planning documents. This strategy will be more meaningful if village heads and/or community representatives are included in the higher planning process (eg. Musrenbang Regency or Province). This is in line with Law No. 25 of 2004 concerning The National Development Planning System and Circular Letter with the Minister of State for National Development Planning /Head of Bappenas Number 0259/M.PPN/I/2005 dated January 20, 2005, concerning Procedures for Organizing Development Deliberations 2005.

Furthermore, fostering and maintaining local /rural institutions that exist and have been entrenched in people's lives so that their existence becomes an integral part of the life of the village community (Chotimah, Widodo, \& Handayani, 2019; Richter, 2019). Based on experience shows that local organizations are a very important factor in supporting the success of development in rural areas. Considering agriculture is the dominant business, the empowerment of farming groups becomes very important. To support village development, an institution can have several functions (multi-function) without having to change the institution itself, if the institution can provide / meet the specified needs. So that the institutional tourism village which is referred to here will be able to encourage appropriate strategies that involve all elements of society and encourage the involvement of all elements of society in building tourist villages and fulfilling the achievement of tourism village elements which have the potential to continue to be developed such as tourism activities and 
attractions so that it will attract investors because of the potential investment there.

\section{CONCLUSIONS}

The criteria of tourism villages used as verification instruments consist of eleven elements, among others: Identity, Regional, TouristAttraction, Activities, Acces-sibility and Ease of Mobility of Travelers, Amenities, Community Empowerment, Investment, Tourism Business, Institutional, and Marketing. The eleven elements have several indicators that vary according to the level of meaning and urgency of each. Each indicator has different weights according to expert engagement and urgency in each location that may vary.

This study uses qualitative approach with holistic approach and learning with the help of instruments obtained from literature studies. This approach still needs to be further tested with different research objects so as to provide a clearer picture related to the reliability of verification instruments and still the lack of resource persons obtained in this study due to the pandemic that causes difficult access to personal approaches to gain a level of trust in the discussions built between researchers and resource persons. It takes enough time to explain one instrument at a time to avoid the incomprehension of the source to the questions and instruments being studied.

\section{REFERENCES}

Andoko, E. (2019). Analysis of Indonesia' Government Strategy for Rural Development through Agriculture. FFTC Agricultural Policy Platform (FFTC-AP). Retrieved from https://ap.fftc.org.tw/ article/1612

Budhi Pamungkas Gautama, Yuliawati, A. K., Nurhayati, N. S., Fitriyani, E., \& Pratiwi, I. I. (2020). PENGEMBANGAN DESA WISATA MELALUI PENDEKATAN PEMBERDAYAAN MASYARAKAT. Jurnal Pengabdian Kepada Masyarakat, 1(4), 355-369. https://doi.org/10.31949/ jb.v1i4.414
Chotimah, C., Widodo, R., \& Handayani, T. (2019). EFEKTIVITAS LEMBAGA PEMBERDAYAAN MASYARAKATDESADALAMPELAKSANAAN PEMBANGUNAN DESA BULULAWANG. Jurnal Civic Hukum, 4(2), 103. https://doi.org/10.22219/jch. v4i2.9184

Faizal Rachman, A., \& Suprina, R. (2019). Pendampingan Desa Cipasung Menuju Desa Wisata. Jurnal Pemberdayaan Pariwisata, 1(1), 9-20. Retrieved from http://jurnalpariwisata.stptrisakti.ac.id/index. php/JPP/article/view/1323

Hidayati, K., \& Nugrahani, H. S. D. (2021). Pengelolaan Desa Wisata Bahari Berkelanjutan Dalam Perspektif Ketahanan Nasional. Jurnal Syntax Admiration, 1(9), 94-103. Retrieved from http:// jurnalsyntaxadmiration.com/index.php/jurnal/ article/view/168

Nayati Utami, H., \& Ruhana, I. (2019). Pemberdayaan Masyarakat dengan Pendekatan Triple Helix untuk Pengembangan Kompetensi Wirausaha Masyarakat Desa Mandiri Energi. In JIAP (Vol. 5). Retrieved from https://jiap.ub.ac.id/index.php/jiap/article/ view/1003

Richter, R. (2019). Rural social enterprises as embedded intermediaries: The innovative power of connecting rural communities with supra-regional networks. Journal of Rural Studies, 70, 179-187. https://doi. org/10.1016/j.jrurstud.2017.12.005

Roundy, P. T. (2019). "It takes a village" to support entrepreneurship: intersecting economic and community dynamics in small town entrepreneurial ecosystems. International Entrepreneurship and Management Journal, 15(4), 1443-1475. https:// doi.org/10.1007/s11365-018-0537-0

Subarkah, A. R. (2018). Potensi dan Prospek Wisata Halal Dalam Meningkatkan Ekonomi Daerah (Studi Kasus: Nusa Tenggara Barat). JURNAL SOSIAL POLITIK, 4(2), 49. https://doi.org/10.22219/sospol. $\mathrm{v} 4 \mathrm{i} 2.5979$ 